\title{
Retailers and Customers: Problems and Perspectives
}

\author{
${ }^{1}$ Surajit Dey, ${ }^{2}$ Dr. Sameena Rafat, ${ }^{3}$ Alam Sageer \\ ${ }^{1}$ (Research Scholar, Department of management, CMJ University, India) \\ ${ }_{2}^{2}$ (Asst. Professor, IIPM, Lucknow, India) \\ ${ }_{3}^{3}$ (Management Faculty, Wisdom School of Management, India)
}

\begin{abstract}
The retail scenario is one of the fastest growing industries in India over the last couple of years. India retail sector comprises of organized retail and unorganized retail sector. Traditionally the retail market in India was largely unorganized; however with changing consumer preferences, organized retail is gradually becoming popular. Unorganized retailing consists of small and medium grocery store, medicine stores, subzi mandi etc. More than $90 \%$ of retailing in India fall into the unorganized sector, the organized sector is largely concentrated in big cities. Organized retail in India is expected to grow 25-30 per cent yearly and is expected to increase from Rs35, 000 crore in 2004-05 to Rs109, 000 crore (\$24 billion) by 2010.
\end{abstract}

\section{Introduction}

Retailing is the activity of selling goods and services to a final consumer for his own use. It is concerned with getting goods in their finished state into the heads of customers who are prepared to pay for the pleasure of eating, wearing or experiencing particular products items. Retailing is all about distribution of goods and services. Retailers form the link between the manufacturers, wholesalers, agents and the customers. They are the persons who keep in touch with the customers and get an opportunity to understand their needs and preferences.

The retail sector in India is witnessing unparalleled growth. Unmatched demographics, rising income levels, shifting lifestyles and changing aspirations of the burgeoning middleclass has unleashed a retail revolution in the country. Fresh retail geographies are emerging, innovative formats are being introduced and retailers are tapping new customer segments with prolific product offerings.

\section{Statement Of The Problem}

In this competitive world, we can see many problems in marketing of any product or service. Some problems can be solved, but so many problems may not be solved. India is a developing country and retail marketing is an important one to develop a country's economy. Retailers, who are the connecting link between the producer and consumer, face many problems to market their products from various dimensions and many causes behind this. At present the customers are also more dynamic. The customers have certain expectations from the items they purchase such as its quality, price, good services etc. Hence, there is a need for a research work in the field of problems of retail marketing in the point of view of retailers and customers as well.

\section{Review Of Literature}

Review of previous studies is essential for every research to carry on investigation successfully. Hence, the present study is also based on the following reviews.

Amuthan.R. (2004) studied "A study on Retail Banking strategies of private sectors Banks with special reference to HDFC bank \& ICICI Bank". It is only their continued thrust and world class banking made them yielding the net profit of Rs.387 crores and Rs. 1206 crores respectively.

Thirumoorthi.P. (2006) studied in his research about "A study on retailers and customer attitude towards P \& G Detergent Powder". It can be concluded that the company must concentrate more on high margin to create a better performance. Importance must be given to sales promotion. The retailers must also be asked to give more displays and discounts. Thus it can be concluded that the customer and retailer attitude towards the $\mathrm{P}$ $\& \mathrm{G}$ detergent powder is positive.

Suresh (2007) studied in his research about "Buying Behaviour and promotion in Textile Retailing and concluded that increase in turnover should be achieved by reducing the margin in this competitive era to survive in the long run. Keep updates about the price fluctuations and new fashions in the supplier market. Always be in a receptive mood to know the preference and taste of customers".

Tamilarasan.R. (2007) in his study focused to "A study on Retail store service Quality Dimensions in select Retail stores". This study after an in depth analysis of a variety of store dimensions and services quality dimensions reveals that all these dimensions have to be improved to earn a competitive edge and survive in the 
retail Business in view of the changing and emerging retail scenario, in India with the possible advent of the MNC's in the retail Indian Market Scenario.

LaxmiPrabha.G. (2007) in her study focused to study "the prospects and problem of Indian Retailing" one of the major concerns of retail is "shoplifting", shoplifters use different shoplifting techniques for the theft. It is done deliberately with the intention of robbing the processor for the particular piece of property that has been stolen from the retail establishment.

Amatual Baseer (2007) studied in his research about "Emerging Trends in India", The demanding ascertain Indian consumer is now sowing the seeds for an exciting retail transformation that he already started bringing in larger interest from international brands / formats. With the advent of these players, the race is on to please the Indian customer and its time for the Indian customer sit back and enjoys the hospitality of being treated like a King.

Rathanyake (2008) studied in his research about "customer complaining Behaviour in Retailing", proper understanding of the dynamics of customer complaining behaviour support the retailer to treat the customers who are not satisfied with the retail Experience.

Hariharan.G. (2008) in his study "profile and perception of retail consumers", analyzed the consumers perception towards retail, in Palakkad. Visiting retail outlets has become a group activity. Most of the shoppers are influenced by as well as accompanied by colleagues, friend and relatives. Majority of the people who visit do not shop at all. The hang around meet friends, do window - shopping and spend time leisurely.

\section{Objectives Of The Study}

The specific objectives of the study are as follows.

- To ascertain the problems of retailers

- To evaluate the causes of problems in retail business

- To identify the satisfaction level of customers towards retailing services

- To analyse the problems faced by the customers in retail marketing

\section{Methodology-Data}

The present study intends to examine the issues framed in the objectives relating to the problems in Retail Marketing. The study is an empirical research based on survey method and the data collected for the study includes only primary data. The primary data have been collected through the survey method by direct personal interview with the sample respondents. The required primary data for the present study were collected from 100 sample respondents by using interview schedule method. For the present study, among various retail markets available in Pollachi Town, food and grocery retail markets have been selected by considering their market share.

\section{Sampling Design}

The sample size of the study is taken as 100 which consist of 50 customers and 50 retailers. A sample obtained from customers' includes regular customers (per month) and temporary customers who have previous dealing with the retailers and a sample obtained from retailers include food and grocery retailers. Convenience sampling method is employed for data collection from both the retailers and customers.

\section{VII. $\quad$ Frame Work And Tools Used For Analysis}

Data collected through interview schedule were presented in a master table and required sub tables were prepared. The statistical tools such as Percentage analysis, Weighted ranking analysis, Garrett's ranking analysis, Likert's scaling technique and Chi-square analysis were applied which are considered appropriate to this study. Statistical package 17.0 was employed to work out certain calculations.

\section{Area And Period Of The Study}

The area of the study is confined to Pollachi town, Coimbatore district. The data was collected through the questionnaire.

\section{Problems Faced By The Retailers}

In the present study an attempt is made to analyse the problems faced by the retailers by using weighted ranking method and the problems are categorized into four viz. problems from employees, problems from customers, problems from dealers and problems in terms of finance. 


\section{Problems From Employees- Weighted Ranking Analysis}

Here, an attempt is made to analyse the problems of retailers from employees by using weighted ranking analysis.

Table 1 -Problems from Employees - Weighted Ranking Analysis

\begin{tabular}{|l|l|c|c|}
\hline S.No. & Reasons & $\begin{array}{l}\text { Weighted } \\
\text { Score }\end{array}$ & Rank \\
\hline 1 & Untrained employees & 166 & II \\
\hline 2 & Laziness of the employees & 148 & III \\
\hline 3 & Lack of reliability & 174 & I \\
\hline 4 & Irresponsible approach with customer & 135 & IV \\
\hline 5 & Poor co-operation with co-workers & 127 & V \\
\hline
\end{tabular}

Source: Primary Data

It is clear from the Table that lack of reliability is ranked as the first and foremost problem faced by the retailers in the study area as its score is higher than others followed by untrained employees and laziness of the employees.

XI. Problems From Customers - Weighted Ranking Analysis

Here, an attempt is made to analyse the problems of retailers from customers by using weighted ranking analysis.

Table 2 -Problems from the Customers- Weighted Ranking Analysis

\begin{tabular}{|l|l|c|c|}
\hline S.No & . Reasons & $\begin{array}{l}\text { Weighted } \\
\text { Score }\end{array}$ & Rank \\
\hline 1 & Over bargaining & 178 & III \\
\hline 2 & Expecting discount \& offers & 186 & II \\
\hline 3 & Seeking credit facility & 175 & IV \\
\hline 4 & Bad debts & 232 & I \\
\hline 5 & Hard in approach & 136 & VI \\
\hline 6 & Misbehavior & 143 & V \\
\hline
\end{tabular}

Source: Primary Data

It can be concluded from Table that among the various problems of retailers Bad debts is the main problem faced by them from customers followed by more expectation of discount and offers and over bargaining.

XII. Problems From Dealers - Weighted Ranking Analysis

Here, an attempt is made to analyse the problems of retailers from dealers by using weighted ranking analysis.

Table 3 -Problems from the Dealers- Weighted Ranking Analysis

\begin{tabular}{|c|l|c|c|}
\hline S.No & Reasons & Weighted Score & Rank \\
\hline 1 & Price variation & 285 & I \\
\hline 2 & Delay in delivery & 220 & V \\
\hline 3 & Poor market information & 212 & VII \\
\hline 4 & Irregular motivation in terms of award and gift & 147 & VIII \\
\hline 5 & Poor credit facility & 237 & III \\
\hline 6 & Low profit margin & 263 & II \\
\hline 7 & Supply of out dated products & 216 & VI \\
\hline 8 & Poor delivery & 229 & IV \\
\hline
\end{tabular}

It can be elucidated from the above Table that price variation is the main problem faced by the retailers from dealers. Low profit margin and poor credit facility are considered as other major problems of retailers from the dealers. 


\section{Problems In Terms Of Finance - Weighted Ranking Analysis}

Here, an attempt is made to analyse the problems of retailers in terms of finance by using weighted ranking analysis.

Table 4 -Problems in terms of Finance- Weighted Ranking Analysis

\begin{tabular}{|l|l|c|c|}
\hline S.No & Reasons & Weighted & Rank \\
\hline 1 & Unavailability of loan / CC from banks & 133 & V \\
\hline 2 & Requirement of more working capital & 151 & II \\
\hline 3 & Limited credit period from dealers & 144 & III \\
\hline 4 & Limited financial resources & 182 & I \\
\hline 5 & Poor recovery of accounts receivable & 138 & IV \\
\hline
\end{tabular}

Source: Primary Data

It can be concluded from Table that bad debts is the main problem faced by the retailers from the customers. Requirement of more working capital and limited credit period from dealers are identified as other major problems faced by retailers in terms of finance.

\section{XIV. $\quad$ Causes Of Problems In Retail Business}

Here, an attempt is made to analyse the causes of problems in retail business by using weighted ranking analysis.

Table 5 -Causes of Problems in Retail Business - Weighted Ranking Analysis

\begin{tabular}{|c|l|c|c|}
\hline S.No & - Reasons & $\begin{array}{l}\text { Weighted } \\
\text { Score }\end{array}$ & Rank \\
\hline 1 & Limited financial resources & 246 & II \\
\hline 2 & Lack of experience & 273 & I \\
\hline 3 & Change in Outlook of Customers & 214 & VII \\
\hline 4 & Long credit period allowed & 238 & VI \\
\hline 5 & Inconvenient Location & 245 & IV \\
\hline 6 & Lack of customer's awareness & 240 & V \\
\hline 7 & Poor market condition & 247 & \\
\hline
\end{tabular}

Source: Primary Data

Table reveals that among the various causes of problems faced by the retailers lack of experience is the first and foremost cause. Poor market condition and limited financial resources are other major causes for problems of retailers.

\section{XV. $\quad$ Association Between The Socio - Economic Factors Of Customers And Their Level Of}

\section{Satisfaction Towards Retail Services}

It is decided to analyse the Satisfaction Level of Customers towards Retail Services Offered by considering the following factors price, co-operation of the employees, reply on enquiry, parking facility, toilet facility, availability of products, location convenience, proper cleaning of the shop, availability of all the goods, air ventilation, proper arrangement of goods, quality of products, availability of branded products, provision of door delivery and after sales service.

Table 6 -Satisfaction Level of Customers towards Retail Services Offered: Chi-square Analysis

\begin{tabular}{|l|c|c|c|c|}
\hline $\begin{array}{l}\text { Socio-economic } \\
\text { Factors }\end{array}$ & $\begin{array}{l}\text { Degrees } \\
\text { of }\end{array}$ & $\begin{array}{l}\text { Chi-square } \\
\text { Calculated }\end{array}$ & $\begin{array}{l}\text { Chi-square } \\
\text { Table value }\end{array}$ & S/NS \\
\hline Age & 4 & 2.870 & 9.488 & NS \\
\hline Gender & 2 & 0.527 & 5.991 & NS \\
\hline Education & 6 & 6.965 & 12.592 & NS \\
\hline Occupation & 8 & 15.601 & 15.507 & S \\
\hline Marital Status & 2 & 5.783 & 5.991 & NS \\
\hline No. of Members & 4 & 5.335 & 9.488 & NS \\
\hline Annual Income & 4 & 8.160 & 9.488 & NS \\
\hline
\end{tabular}

Source: Primary Data. S-Significant; NS- Not Significant; Level of Significance-0.05; 
By applying chi-square test, it is found that there is a significant relationship between occupation of the customers and their satisfaction level. By applying chi-square test, it is also found that there is an insignificant relationship between the age, gender, educational qualification, marital status, number of members in a family and annual income of the customers and their satisfaction level.

Table 7 - Overall Satisfaction Level of Customers towards Retailing Service

\begin{tabular}{|l|l|l|}
\hline Satisfaction Level & No. of Respondents & Percentage \\
\hline High 1 & 19 & 38 \\
\hline Moderate & 21 & 42 \\
\hline Low & 10 & 20 \\
\hline Total & 50 & 100 \\
\hline
\end{tabular}

Source: Primary Data

From the above Table it is found that $38 \%$ of the respondents are highly satisfied, $42 \%$ of the respondents are moderately satisfied and only $20 \%$ of the respondents are less satisfied with regard to various services offered by the retailers.

Table 8 -Age and Satisfaction Level of Customers towards Retailing Service

\begin{tabular}{|l|c|c|c|c|}
\hline \multirow{2}{*}{ Age } & \multicolumn{3}{|c|}{ Satisfaction Level } & \multirow{2}{*}{ Total } \\
\cline { 2 - 4 } & Low & Moderate & High & \\
\hline Below 30 years & 5 & 9 & 13 & 27 \\
& $(18.5 \%)$ & $(33.33 \%)$ & $(48.14 \%)$ & $(100 \%)$ \\
\hline 30 to 40 years & 4 & 9 & 5 & 18 \\
& $(22.22 \%)$ & $(50 \%)$ & $(27.78 \%)$ & $(100 \%)$ \\
\hline Above 40 years & 1 & 3 & 1 & 5 \\
& $(20 \%)$ & $(42 \%)$ & $(38 \%)$ & $(100 \%)$ \\
\hline \multirow{2}{*}{ Total } & 10 & 21 & 19 & 50 \\
& $(20 \%)$ & $(42 \%)$ & $(38 \%)$ & $(100 \%)$ \\
\hline
\end{tabular}

Source: Primary Data

From the above Table it is found that $48.14 \%$ of the respondents belonging to the age group below 30 years are highly satisfied. It is also found that $22.22 \%$ of the respondents of age group between 30 and 40 are less satisfied.

Table 9 -Gender and Satisfaction Level of Customers towards Retailing Service

\begin{tabular}{|l|c|c|l|c|}
\hline \multirow{2}{*}{ Gender } & \multicolumn{3}{|c|}{ Satisfaction Level } & \multirow{2}{*}{ Total } \\
\cline { 2 - 4 } & Low & Moderate & High & \\
\hline Male & 5 & 8 & 7 & 20 \\
$(25 \%)$ & $(40 \%)$ & $(35 \%)$ & $(100 \%)$ \\
\hline Female & 5 & 13 & 12 & 30 \\
& $(16.67 \%)$ & $(43.33 \%)$ & $(40 \%)$ & $(100 \%)$ \\
\hline Total & 10 & 21 & 19 & 50 \\
& $(20 \%)$ & $(42 \%)$ & $(38 \%)$ & $(100 \%)$ \\
\hline
\end{tabular}

Source: Primary Data

It is found that $40 \%$ of the female respondents are highly satisfied. It is also found that $25 \%$ of the male respondents are less satisfied. 
Table 10 -Education and Satisfaction Level of Customers towards Retailing Service

\begin{tabular}{|l|c|c|c|c|}
\hline \multirow{2}{*}{ Education Level } & \multicolumn{3}{|c|}{ Satisfaction Level } & \multirow{2}{*}{ Total } \\
\cline { 2 - 4 } & Low & Moderate & High & \\
\hline School level & 2 & 3 & 2 & 7 \\
& $(28.6 \%)$ & $(42.9 \%)$ & $(28.6 \%)$ & $(100 \%)$ \\
\hline College level & 7 & 11 & 16 & 34 \\
& $(20.58 \%)$ & $(32.35 \%)$ & $(47.05 \%)$ & $(100 \%)$ \\
\hline Professionals & 1 & 6 & 1 & 8 \\
& $(12.5 \%)$ & $(75 \%)$ & $(12.5 \%)$ & $(100 \%)$ \\
\hline Illiterate & 0 & 1 & 0 & 1 \\
& $(0 \%)$ & $(100 \%)$ & $(0 \%)$ & $(100 \%)$ \\
\hline Total & $(20 \%)$ & 10 & 19 & 50 \\
& 21 & $(42 \%)$ & $(38 \%)$ & $(100 \%)$ \\
\hline
\end{tabular}

Source: Primary Data

It is found that $47.05 \%$ of the respondents having college level education are highly satisfied. It is also found that $28.6 \%$ of the respondents having school level education are less satisfied.

Table 11 -Occupation and Satisfaction Level of Customers towards Retailing Service

\begin{tabular}{|l|c|c|c|c|}
\hline \multirow{2}{*}{ Occupation } & \multicolumn{3}{|c|}{ Satisfaction Level } & \multirow{2}{*}{ Total } \\
\cline { 2 - 4 } & Low & Moderate & High & \\
\hline Business People & 2 & 3 & 7 & 12 \\
& $(16.67)$ & $(25 \%)$ & $(58.33 \%)$ & $(100 \%)$ \\
\hline Govt. employees & 1 & 1 & 3 & 5 \\
& $(20 \%)$ & $(20 \%)$ & $(60 \%)$ & $(100 \%)$ \\
\hline Private employee & 3 & 8 & 7 & 18 \\
& $(16.67 \%)$ & $(44.44 \%)$ & $(38.89 \%)$ & $(100 \%)$ \\
\hline Professionals & 1 & 2 & 1 & 4 \\
& $(25 \%)$ & $(50 \%)$ & $(25 \%)$ & $(100 \%)$ \\
\hline Total & 10 & 21 & 19 & 50 \\
& $(20 \%)$ & $(42 \%)$ & $(38 \%)$ & $(100 \%)$ \\
\hline
\end{tabular}

Source: Primary Data

It is found that $60 \%$ of the Government employees are highly satisfied. It is also found that $45.45 \%$ of the agriculture respondents are less satisfied.

Table 12 -Marital Status and Satisfaction Level of Customers towards Retailing Service

\begin{tabular}{|l|l|l|l|l|}
\hline \multirow{2}{*}{ Marital Status } & \multicolumn{2}{|l|}{ Satisfaction Level } & \multirow{2}{*}{ Total } \\
\cline { 2 - 4 } & Low & Moderate & High & \\
\hline Single & $\begin{array}{l}4 \\
(15.38 \%)\end{array}$ & $\begin{array}{l}8 \\
(30.76 \%)\end{array}$ & $\begin{array}{l}14 \\
(53.84 \%)\end{array}$ & $\begin{array}{l}26 \\
(100 \%)\end{array}$ \\
\hline Married & 6 & $\begin{array}{l}13 \\
(54.17 \%)\end{array}$ & $\begin{array}{l}5 \\
(20.83 \%)\end{array}$ & $\begin{array}{l}24 \\
(100 \%)\end{array}$ \\
\hline Total & $\begin{array}{l}(25 \%) \\
\end{array}$ & $\begin{array}{l}21 \\
(20 \%)\end{array}$ & $\begin{array}{l}19 \\
(38 \%)\end{array}$ & $\begin{array}{l}50 \\
(100 \%)\end{array}$ \\
\hline
\end{tabular}

Source: Primary Data 
It is found that $53.84 \%$ of the single respondents are highly satisfied. It is also found that $15.38 \%$ of the married respondents are less satisfied.

Table 13 -Annual Income and Satisfaction Level of Customers towards Retailing Service

\begin{tabular}{|l|c|c|c|c|}
\hline \multirow{2}{*}{ Annual Income } & \multicolumn{3}{|c|}{ Satisfaction Level } & \multirow{2}{*}{ Total } \\
\cline { 2 - 4 } & Low & Moderate & High & \\
\hline Below Rs.50000 & 6 & 7 & 13 & 26 \\
& $(23.08 \%)$ & $(26.92 \%)$ & $(50 \%)$ & $(100 \%)$ \\
\hline Rs.50000 to Rs.100000 & 3 & 7 & 3 & 13 \\
& $(23.08 \%)$ & $(25.84 \%)$ & $(23.08 \%)$ & $(100 \%)$ \\
\hline Above Rs.100000 & 1 & 7 & 3 & 11 \\
& $(9.09 \%)$ & $(63.63 \%)$ & $(27.28)$ & $(100 \%)$ \\
\hline Total & 10 & 21 & 19 & 50 \\
& $(20 \%)$ & $(42 \%)$ & $(38 \%)$ & $(100 \%)$ \\
\hline
\end{tabular}

Source: Primary Data

It is found that $48.15 \%$ of the respondents having annual income of below Rs.50000 are highly satisfied. It is also found that $25.92 \%$ of the respondents from the same category are less satisfied.

Table 14 -No. of Members and Satisfaction Level of Customers towards Retailing Service

\begin{tabular}{|l|c|c|l|c|}
\hline $\begin{array}{l}\text { No. of } \\
\text { Members }\end{array}$ & \multicolumn{3}{|c|}{ Satisfaction Level } & \multirow{2}{*}{ Total } \\
\cline { 2 - 4 } & Low & Moderate & High & \\
\hline $1-2$ & 3 & 4 & 1 & 8 \\
& $(37.5 \%)$ & $(50 \%)$ & $(12.5 \%)$ & $(100 \%)$ \\
\hline $3-5$ & 6 & 15 & 14 & 35 \\
& $(17.14 \%)$ & $(42.86 \%)$ & $(40)$ & $(100 \%)$ \\
\hline Above 5 & 1 & 2 & 4 & 7 \\
& $(14.29)$ & $(28.57 \%)$ & $(57.14 \%)$ & $(100 \%)$ \\
\hline Total & 10 & $\begin{array}{c}21 \\
(20 \%)\end{array}$ & $\begin{array}{c}19 \\
(38 \%)\end{array}$ & $\begin{array}{c}50 \\
(100 \%)\end{array}$ \\
\hline
\end{tabular}

Source: Primary Data

It is found that $51.72 \%$ of the respondents having wealth of below Rs.5 Lakh are highly satisfied. It is also found that $31.25 \%$ of the respondents having wealth of Rs.5-10 Lakh are less satisfied.

XVI. Problems Faced By Customers While Utilizing Retail Services

There are numerous problems faced by the customers while they purchase their products from their retailers. The following Tables show the problems of customers from retailers and employees, problems in terms of product, accessibility and physical appearance.

Table 15 -Problems of Customers in terms of Product - Garrett Ranking Analysis

\begin{tabular}{|l|c|c|c|}
\hline Problems & $\begin{array}{l}\text { Total } \\
\text { Score }\end{array}$ & Mean Score & Rank \\
\hline Adulterated products & 2740 & 54.8 & II \\
\hline Poor quality of products & 2266 & 45.32 & IV \\
\hline Higher Price & 2886 & 57.72 & I \\
\hline Higher Price & 1953 & 39.06 & IV \\
\hline
\end{tabular}

Source: Primary Data 
It is clear from the Table that higher price is the major problem faced by the customers in terms of product followed by adulterated products, poor quality of products and poor package.

Table 16 -Problems of Customers in terms of Accessibility - Garrett Ranking Analysis

\begin{tabular}{|l|c|c|c|}
\hline \multicolumn{1}{|c|}{ Problems } & $\begin{array}{l}\text { Total } \\
\text { Score }\end{array}$ & $\begin{array}{l}\text { Mean } \\
\text { Score }\end{array}$ & Rank \\
\hline Non availability of goods at all time & 2725 & 54.5 & II \\
\hline Unavailability of branded products & 3150 & 63.0 & I \\
\hline No door delivery & 1831 & 36.62 & IV \\
\hline Poor after sales service & 2253 & 45.06 & III \\
\hline
\end{tabular}

Source: Primary Data

It is clear from the Table that unavailability of branded products is identified as the major problem in terms of accessibility followed by non availability of goods at all time, poor after sales service and no door delivery.

Table 17 -Problems of Customers from Employees and Retailers - Garrett Ranking Analysis

\begin{tabular}{|l|c|c|c|}
\hline \multicolumn{1}{|c|}{ Problems } & Total Score & Mean Score & Rank \\
\hline Price Discrimination & 3366 & 67.32 & I \\
\hline Poor reply on enquiry & 2966 & 59.32 & IV \\
\hline Lack of knowledge & 3176 & 63.52 & II \\
\hline Poor co-operation of the employees & 1622 & 32.44 & VI \\
\hline Selling expired products & 2743 & 54.86 & V \\
\hline Doing Adulteration & 3089 & 61.78 & III \\
\hline
\end{tabular}

Source: Primary Data

It is clear from the Table that price discrimination is the major problem faced by the customers from employees and retailers followed by lack of knowledge, doing adulteration, poor reply on enquiry, selling expired products and poor co-operation of the employees.

Table 18 -Problems of Customers in terms of Physical Appearance - Garrett Ranking Analysis

\begin{tabular}{|l|c|c|c|}
\hline Problems & Total Score & MeanScore & Rank \\
\hline Inconvenient Parking facilitv & 3468 & 69.36 & I \\
\hline Inconvenient toilet facility & 2335 & 46.7 & VI \\
\hline Inconvenient location & 3009 & 60.18 & III \\
\hline No proper cleaning of the shop & 2599 & 51.98 & V \\
\hline Worst air ventilation & 2939 & 58.78 & IV \\
\hline Improper arrangement of goods & 3249 & 64.98 & II \\
\hline
\end{tabular}

Source: Primary Data

It is clear from the Table that inconvenient parking facility is the major problem faced by the customers in terms of physical appearance followed by improper arrangement of goods, inconvenient location, worst air ventilation, no proper cleaning of the shop and inconvenient toilet facility.

\section{Suggestions}

- It is found that majority of the retailers are suffering from the problem of bad debts. Though bad debts are unavoidable in business, it can be minimised. For that it is suggested that the retailers should maintain friendly relationship with their customers, must assess the credit worthiness of their customers before allowing credit and allowing credit sales only to the regular customers. Then only the retailers can escape from this critical problem.

- It is found that majority of the sample respondents are suffering from the problem of limited financial resources. Hence, it is suggested that the government should provide financial facility (short term and medium term loans) to those retailers who are financially weak.

- It is found that majority of the sample respondents ranked poor market condition as their major problem. Hence, it is suggested to the retailers could successfully market their products by more careful identification of market segments and providing service superior to that of the competitors. It is found that there is a significant relationship between occupation and problem faced by the customer. Hence it is suggested to the retailer that may try to cater the needs of different occupation group of people by selling the products at reasonable price, ensuring the availability of branded and non-branded products etc. 
- It is found that price discrimination by the employees and retailers is considered as major problem to the customers. Hence, it is suggested that the retailers and employees should try to follow some ethics in price fixation and avoid the discrimination in fixing price failure of which would dampen their business growth in a long run.

\section{Conclusion}

Retail is clearly the sector that is poised to show the highest growth in the next five years. The sector is set for a revolution, as both the present players and new entrants are gearing up to explore the market. This sector contributes $10 \%$ of India's GDP and the current growth rate is $8.5 \%$. The present size of the organized retailing sector is approximately $3 \%$ and is expected to grow to $25-30 \%$ by the year 2010 . There are about 300 new malls, 1500 supermarkets and 325 departmental stores currently under construction. Based on the findings of the study, various suggestions were made. If those will be properly considered by the retailers, preferred result could be accomplished.

\section{Books}

\section{References}

[1] Kothari.C.R, Research Methodology, New Age (P) Limited, Second Edition, 2004.

[2] Pillai \& Bagavathi, Marketing management, New Delhi, sultan Chand \& Sons, 1999.

[3] David Gilbert, Retail Marketing Management, Prentice Hall, Second Edition, 2003.

\section{Journals}

[4] Amatual Baseer (2007), "Emerging Trends in India”, Indian Journal of Marketing, Vol. XXXVII, No.11, pp

[5] Amuthan .R. (2004), “A study on Retail Banking strategies of private sectors Banks with special reference to HDFC bank \& ICICI Bank”, 2004, Vol. XXXIV, No.12, pp

[6] Hariharan.G. (2008), "Profile and perception of retail consumers", Indian Journal of Marketing, Vol. XXXVIII, No.2, pp

[7] Laxmi Prabha.G. (2007), "The prospects and problems of Indian Retailing”, Indian Journal of Marketing, Vol. XXXVII, No.10, pp

[8] Rathanyake (2008), "customer complaining Behaviour in Retailing”, Indian Journal of Marketing, Vol. XXXVIII, No. 8, pp

[9] Suresh (2007), "Buying Behaviour and promotion in Textile Retailing", Indian journal of marketing, Vol: XXXVII, No.7, pp

[10] Tamilarasan.R. (2007), "A study on retail store service quality dimensions in select retail store of Chennai", Indian Journal of Marketing, Vol. XXXVII, No.7, pp

[11] Thirumoorthi.P. (2006), "A study on retailers and customer attitude towards P \& G Detergent Powder", Indian Journal of Marketing, Vol. XXXVI, No.9, pp

\section{Websites}

[12] Google (2010), http://www.google.co.in, Accessed on12th February 2010

[13] Ibef (2010) http://www.ibef.org, Accessed on12th February 2010

[14] Business maps of India (2010) http://www.business.mapsofindia.com, Accessed on12th February 2010

[15] Icmr India (2010) http://www.icmrindia.org, Accessed on12th February 2010

[16] Research and markets (2010) http://www.researchandmarkets.com, Accessed on12th February 2010 